- FINANSE I PRAWO FINANSOWE.

- Journal of Finance and Financial Law •

Marzec/March 2019 • vol. 1(21): 39-54

http://dx.doi.org/10.18778/2391-6478.1.21.04

\title{
ŚRODKI POMOCOWE UE W FINANSOWANIU GOSPODARSTW ROLNYCH - STUDIUM PRZYPADKU
}

\author{
Jakub Milczarek \\ Wydział Ekonomiczno-Socjologiczny, Uniwersytet Łódzki
}

\begin{abstract}
Streszczenie
Artykuł dotyczy znaczenia funduszy europejskich w finansowaniu gospodarstw rolnych w Polsce. W ciągu ostatnich lat, w wyniku transformacji systemowej oraz akcesji Polski w struktury Unii Europejskiej sektor rolniczy w Polsce bardzo się zmienił. Aby zachować konkurencyjność, gospodarstwa muszą nieustannie dokonywać modernizacji parku maszynowego. Środki pomocowe Unii Europejskiej są obecnie jednym z podstawowych źródeł finansowania zakupu nowych maszyn. Sektor rolniczy w Unii Europejskiej traktowany jest priorytetowo. Każdego roku połowa budżetu Unii Europejskiej przeznaczana jest na finansowanie rolnictwa. Celem artykułu jest ocena wykorzystania środków pomocowych Unii Europejskiej w finansowaniu gospodarstw rolnych w Polsce.
\end{abstract}

Słowa kluczowe: rolnictwo, fundusze unijne, rozwój rolnictwa, sektor rolniczy.

JEL Class: G28, H7, H71. 


\section{WPROWADZENIE}

Rolnictwo jest jednym z trzech podstawowych sektorów gospodarki narodowej. Gospodarstwa rolne wytwarzają strategiczne dobro, jakim jest żywność. Polskie gospodarstwa są zróżnicowane pod względem wielkości ekonomicznej. Udział rolnictwa w tworzeniu PKB w 2017 r. wyniósł 3,5\%, a ciężka sytuacja w tym sektorze powoduje wyludnianie się i zmianę stylu życia ludności wiejskiej.

Transformacja systemowa w latach 80 . XX wieku w Polsce, a także przemiany polityczno-gospodarcze w Europie Środkowo-Wschodniej postawiły polskie rolnictwo przed szeregiem wyzwań. Z jednej strony, zacofany sektor gospodarki, jakim było rolnictwo, musiał stawić czoła nowoczesnemu rolnictwu Europy Zachodniej, które produkowało wydajniej, przy utrzymywaniu niskich kosztów produkcji. Ponadto, polskie gospodarstwa w krótkim czasie były zobowiązane do dostosowania norm technicznych oraz spełnienia norm prawnych Wspólnoty Europejskiej. Z drugiej strony, akcesja Polski do struktur Unii Europejskiej pozwoliła na skorzystanie z dotacji unijnych. Sektor ten jest traktowany priorytetowo. Pieniądze z budżetu Unii Europejskiej kierowane są do krajów najsłabiej rozwiniętych, w celu wyrównania rozwoju gospodarczego wspólnoty. W wyniku szkoleń organizowanych przez Ośrodki Doradztwa Rolniczego, jak również zainteresowania ze strony rolników, Polska stała się największym beneficjentem środków z budżetu unijnego. W 2017 roku Polska otrzymała $4586 \mathrm{mln}$ euro, a polskie rolnictwo weszło w etap gwałtownego rozwoju oraz całkowitej restrukturyzacji.

Celem artykułu jest ocena wykorzystania środków pomocowych Unii Europejskiej w finansowaniu gospodarstw rolnych w Polce.

W artykule przedstawiono hipotezę mówiącą, że środki pomocowe Unii Europejskiej determinują rozwój ekonomiczny polskich gospodarstw rolnych.

\section{SEKTOR ROLNICTWA W POLSCE}

Gospodarka Polski charakteryzuje się podziałem na sektory. Sektor gospodarki jest to zbiór przedsiębiorstw, których główna dziedzina działalności dotyczy oferowania usług oraz wytwarzania dóbr o podobnym zastosowaniu [Smid 2007: 216]. Możemy wyróżnić trzy podstawowe sektory gospodarki [Runge 2008: 292]:

- sektor pierwszy - rolnictwo, myślistwo, rybołówstwo,

- sektor drugi - przemysł, górnictwo, budownictwo,

- sektor trzeci - obszar obejmujący usługi dotyczące m.in.: transportu, edukacji, ochrony zdrowia, oświaty, administracji. 
Coraz częściej możemy również spotkać się z wyodrębnianiem czwartego sektora, jakim są usługi zawansowane np.: usługi bankowe, finansowe, IT.

Obecnie zgodnie $\mathrm{z}$ teorią trzech sektorów gospodarki stworzonej w latach 30. XX w. przez A.B.G Fishera, C. Clarka i J. Fourastie'go możemy zaobserwować coraz mniejszy udział w zatrudnieniu sektora pierwszego oraz drugiego, obecnie około $15 \%$ w sektorze pierwszym i $25 \%$ w drugim, a wzrost zatrudnienia w sektorze trzecim.

Po 1990 roku rozpoczął się szereg zmian w rozwoju oraz znaczeniu poszczególnych sektorów gospodarczych Polski. Był to okres, w którym Polska odeszła od systemu centralnego planowania oraz przyjęła model gospodarki rynkowej. Przed przedsiębiorstwami otworzył się szereg możliwości, pojawiły się nowe rynki zbytu, a znaczenia nabrała konkurencja. Przedsiębiorstwa państwowe sukcesywnie przechodziły proces prywatyzacji. Gospodarka Polski musiała dokonać gwałtownej transformacji. Struktura zatrudnienia odbiegała znacznie od standardów unijnych, średnie zatrudnienie w rolnictwie, w Polsce, w 2002 r., wynosiło 29,8\% (średnia krajów Wspólnoty 2,5), a w sektorze usług 45,8\% (średnia krajów Wspólnoty 67,4\%) [Szukalski 2004: 53-55].

Transformacja systemowa była bardzo ważnym czynnikiem rozwojowym sektora rolniczego, jednakże dla polskiego rolnictwa przełomowym momentem była akcesja Polski w struktury Unii Europejskiej. Od 2003 roku Polska sukcesywnie zwiększa eksport oraz import produktów krajowych. Obroty polskiego handlu zagranicznego w latach 2003-2004 wzrosły o niemal 30\%. Sam eksport w latach 2003-2013 wzrósł pięciokrotnie, co jest pozytywnym zjawiskiem przy czterokrotnym wzroście importu. Sytuacja ta pozwoliła na stopniowe zdominowanie przez Polskę regionu UE-10, gdzie Polskę pod względem nadwyżki w handlu towarami rolno-spożywczymi przeganiają tylko Węgry. Akcesja Polski do struktur Unijnych pozwoliła pokazać przewagę komparatywną polskiego rolnictwa nad pozostałymi krajami Unii. W Polsce koszty produkcji są znacznie niższe niż w pozostałych państwach Wspólnoty. Natomiast rozwój technologiczny oraz jakość surowców stoją na wyższym poziomie, co pozwala optymistycznie patrzeć w przyszłość polskiego rolnictwa [Józefowicz 2015: 12-22].

Jak wynika $\mathrm{z}$ danych $\mathrm{w}$ tab. 1, najwięcej osób zatrudnionych jest w sektorze III. W 2016 roku w sektorze usług pracowało 58,42\% ogółu pracujących, to o $0,98 \%$ więcej niż w roku 2013. Poziom zatrudnienia w przemyśle wzrósł w latach 2013-2016 o 0,13\%, w 2016 roku w tym sektorze pracowało 3973900 osób. W sektorze I liczba pracujących w 2013 roku wynosiła 2379000 osób, a w 2016 roku 2385 500. Oznacza to, że liczba pracujących wzrosła o 6500 osób. Porównując jednak sektor rolniczy do pozostałych dwóch, jest to jedyny sektor, w którym poziom zatrudnienia względem ogółu pracujących spadł. W 2013 roku poziom zatrudnienia w sektorze I wynosił 16,70\%, natomiast w 2016 roku $15,60 \%$. 
Tabela 1. Zatrudnienie oraz struktura zatrudnienia w poszczególnych sektorach gospodarki

\begin{tabular}{|l|c|c|c|c|}
\hline \multicolumn{5}{|c|}{ Liczba zatrudnionych w poszczególnych sektorach gospodarki } \\
\hline Sektory & 2013 & 2014 & 2015 & 2016 \\
\hline $\begin{array}{l}\text { Sektor I } \\
\text { (rolnictwo) }\end{array}$ & 2379000 & 2384900 & 2384800 & 2385500 \\
\hline $\begin{array}{l}\text { Sektor II } \\
\text { (przemysł) }\end{array}$ & 3682700 & 3775700 & 3843800 & 3973900 \\
\hline $\begin{array}{l}\text { Sektor III } \\
\text { (Usługi) }\end{array}$ & 8182600 & 8402800 & 8601200 & 8933900 \\
\hline Razem & $\mathbf{1 4 2 4 4 ~ 3 0 0}$ & $\mathbf{1 4 5 6 3 4 0 0}$ & $\mathbf{1 4 8 2 9} \mathbf{8 0 0}$ & $\mathbf{1 5 2 9 3 3 0 0}$ \\
\hline $\begin{array}{l}\text { Sektor I } \\
\text { (rolnictwo) }\end{array}$ & $16,70 \%$ & $16,38 \%$ & $16,08 \%$ & $15,60 \%$ \\
\hline $\begin{array}{l}\text { Sektor II } \\
\text { (przemys) }\end{array}$ & $25,85 \%$ & $25,93 \%$ & $25,92 \%$ & $25,98 \%$ \\
\hline $\begin{array}{l}\text { Sektor III } \\
\text { (Usługi) }\end{array}$ & $57,44 \%$ & $57,70 \%$ & $58,00 \%$ & $58,42 \%$ \\
\hline Razem & $\mathbf{1 0 0 , 0 0 \%}$ & $\mathbf{1 0 0 , 0 0 \%}$ & $\mathbf{1 0 0 , 0 0 \%}$ & $\mathbf{1 0 0 , 0 0 \%}$ \\
\hline
\end{tabular}

Źródło: opracowanie własne na podstawie: Roczników statystycznych pracy: 2017, 2012, [dostęp 6.02.2019].

\section{2. ŹRÓDŁA FINANSOWANIA ROLNICTWA W POLSCE}

Gospodarstwo rolne ma kilka różnych metod finansowania swojej działalności. Przyglądając się analizie dochodów ludności wiejskiej, jednoznacznie możemy stwierdzić, iż jest ona zbiorowością niejednorodną [Kłodziński i Dzuna 2005: 130]. Dzieje się tak, ponieważ w zależności od wielkości i mechanizacji gospodarstw ludzie mogą chociażby pracować w mieście. Często jest to także ich główne źródło dochodów. Duża część gospodarstw, zlokalizowanych w pobliżu dużych miast, to gospodarstwa bezrolne, nie posiadające ziemi. W wyniku urbanizacji obszary te zupełnie straciły rolniczy charakter [Zegar 2008: 87-88]. Dzieląc źródła finansowania rolnictwa w Polsce możemy wyróżnić [Koniunktura w gospodarstwach rolnych..., dostęp 25.11.2017]:

- środki własne,

- kredyty,

- płatności bezpośrednie,

- pozostałe fundusze unijne. 
Tabela 2. Wydatki gospodarstw rolnych według źródeł finansowania

\begin{tabular}{|l|c|c|c|c|c|}
\hline \multirow{2}{*}{ Wyszczególnienie } & \multirow{2}{*}{ Ogółem } & \multicolumn{4}{|c|}{ Źródła finansowania działalności rolniczej } \\
\cline { 3 - 6 } & & $\begin{array}{c}\text { Środki } \\
\text { własne }\end{array}$ & Kredyty & $\begin{array}{c}\text { Płatności } \\
\text { bezpośrednie }\end{array}$ & $\begin{array}{c}\text { Pozostałe } \\
\text { fundusze unijne }\end{array}$ \\
\hline $\begin{array}{l}\text { Gospodarstwa ponoszące } \\
\text { wydatki: }\end{array}$ & \multicolumn{5}{|c|}{ W procentach } \\
\hline $\begin{array}{l}\text { Na bieżącą działalność } \\
\text { rolniczą: }\end{array}$ & 95,0 & 95,5 & 93,7 & 96,9 & 95,3 \\
\hline Zakup nawozów & 80,1 & 80,7 & 79,1 & 85,4 & 79,8 \\
\hline Zakup pasz & 49,3 & 49,6 & 53,3 & 50,5 & 55,4 \\
\hline $\begin{array}{l}\text { Zakup środków ochrony } \\
\text { roślin }\end{array}$ & 67,8 & 68,6 & 69,2 & 75,6 & 65,9 \\
\hline Inwestycyjne: & 26,3 & 26,2 & 49,9 & 27,4 & 33,5 \\
\hline $\begin{array}{l}\text { Zakup ciągników, ma- } \\
\text { szyn i urządzeń rolni- } \\
\text { czych }\end{array}$ & 13,6 & 13,6 & 28,6 & 14,3 & 20,3 \\
\hline $\begin{array}{l}\text { Budowa, remont lub } \\
\text { modernizacja budynków } \\
\text { gospodarczych }\end{array}$ & 9,9 & 9,9 & 15,3 & 10,3 & 12,1 \\
\hline Zakup ziemi & 2,6 & 2,5 & 8,2 & 2,8 & 2,4 \\
\hline $\begin{array}{l}\text { Powiększenie stada } \\
\text { podstawowego }\end{array}$ & 2,2 & 2,2 & 4,7 & 2,4 & 3,3 \\
\hline $\begin{array}{l}\text { Inne związane z gospo- } \\
\text { darstwem rolnym }\end{array}$ & 52,8 & 53,3 & 52,2 & 61,8 & 44,0 \\
\hline
\end{tabular}

Źródło: Koniunktura w gospodarstwach rolnych..., [dostęp 25.11.2017].

Jak wynika $\mathrm{z}$ danych $\mathrm{w}$ tab. 2, gospodarstwa niezależnie od źródła, w 2015 roku, najwięcej wydawały na finansowanie bieżącej działalności. Wśród wydatków na bieżącą działalność zdecydowanie przeważał zakup nawozów oraz środków ochrony roślin. W pokrywaniu inwestycji prym wiodło finansowanie kredytowe $(49,9 \%)$, najmniej natomiast dokonywało się ich z wykorzystaniem środków własnych. Inwestycje dotyczyły głównie zakupu sprzętu, a także modernizacji budynków. Gospodarstwa wydawały niewielką część swoich zasobów pieniężnych na zakup ziemi oraz rozwój stada podstawowego.

Zasoby własne to podstawowe źródło, z jakiego gospodarstwo finansuje swoją działalność. Niskie dochody małych gospodarstw powodują jednak sytuację, w której rolnicy poszukują nowych źródeł finansowania. Specyfika zawodu jaki wykonują, pozwala jednak na większą różnorodność ich pozyskiwania. Rolnicy, oprócz pracy w własnym gospodarstwie, mogą także zarabiać poza obrębem swojego gospodarstwa. Pierwszym sposobem jest lokalne przetwarzanie wła- 
snych produktów, mleka na ser lub też owoców na przetwory. W miarę rozwoju i inwestycji, z dodatkowego źródła dochodu może stać się jego głównym kierunkiem produkcji. Przykładem mogą być liczne gospodarstwa ekologiczne, które najczęściej zaczynały od produkcji żywności na małym areale, a wraz z upływem czasu produkcja ekologiczna zajmowała cały obszar gospodarstwa. Plusem takiego rozwiązania może być uzyskanie miana produktu lokalnego, czyli produktu wytwarzanego tradycyjnymi metodami i charakterystycznego dla danego obszaru [Kaleta 2008: 54]. Dobra takie często stają się bardzo znane, za przykład może służyć „,czosnek latowicki” posiadający własną stronę internetową. Sprzyja to zainteresowaniu, a także cenie takich produktów. Kolejnym sposobem na poszerzenie działalności gospodarstwa jest świadczenie usług rolniczych. Może ono polegać na odpłatnym wypożyczaniu swojego sprzętu innym gospodarstwom lub wykonywaniu usług przy pomocy swojego sprzętu. Może to być świadczenie usług komunalnych poprzez pielęgnację poboczy, odśnieżanie, udrażnianie rowów, a także wykonywanie siewu lub zbioru plonów na polu innego rolnika [Kaleta 2008: 55-56].

Kredyty i pożyczki, szczególnie preferencyjne, to istotne źródło finansowania dla gospodarstw rolnych. Istnieje duża liczba gospodarstw, które z ich pomocą stały się konkurencyjne na rynku. W wyniku niskiej rentowności rolnictwa kredyty udzielane są na warunkach preferencyjnych. Kredyty preferencyjne są jednym z działań, jakie podejmuje państwo w celu przebudowy sektora rolnego. Są one zazwyczaj korzystniej oprocentowane od pozostałych. Funkcjonują one na podstawie umów z agencją, a także są dofinansowywane z budżetu państwa przez ARiMR, która spłaca część odsetek [Otta 1998: 19]. Najczęściej zaciągane kredyty dotyczą inwestycji, modernizacji, rozbudowy gospodarstw czy zakupów nowoczesnych maszyn i urządzeń. Kolejną grupą kredytów są kredyty na zakup gruntów. Mają one na celu powiększenie gospodarstwa o powierzchni co najmniej 1 ha. Kredyty dla młodych rolników są stworzone, aby urządzić gospodarstwo rolne, zapewnić rolnikowi i jego rodzinie miejsce zamieszkania, a często również stałe źródło dochodów. Mogą dotyczyć zakupu gruntów, budynków mieszkalnych lub gospodarczych, a także zwierząt gospodarczych czy pasz treściwych. Podstawowym warunkiem takiego kredytu jest wiek rolnika, który nie może przekroczyć 40 lat. Ponadto wymagane jest wykształcenie rolnicze oraz udokumentowane 3 lata pracy $\mathrm{w}$ gospodarstwie rolnym.

\section{3. ŚRODKI UNII EUROPEJSKIEJ W FINANSOWANIU ROLNICTWA}

Płatności bezpośrednie są głównym instrumentem wsparcia, jakie gospodarstwa rolne otrzymują z funduszy unijnych. Początek stosowania dopłat miał miejsce w 1992 r. w ramach reformy MacSharry’ego. Miały one początkowo rekompen- 
sować spadek dochodów spowodowany spadkiem cen gwarantowanych. Od 2003 r. zostały one oddzielone od produkcji rolnej, a ich głównym celem zostało wsparcie dochodów rolniczych, a nie motywacja do zwiększenia produkcji. Pozwoliło to na skupienie się do dostosowania wielkości produkcji do sytuacji rynkowej, a nie wielkością płatności. Obecnie w Unii Europejskiej możemy wyróżnić dwa systemu płatności [Informacja nt. możliwych przesunięć środków..., dostęp 24.11.2017]:

- system płatności podstawowej (państwa UE-15, Chorwacja, Malta, Słowenia),

- system jednolitej płatności obszarowej (państwa które przystąpiły do UE w 2004 r. lub później, z wyjątkiem Chorwacji, Malty, Słowenii).

W Polsce korzystano z systemu jednolitej płatności obszarowej. Oznaczało to, że świadczenia były proporcjonalne do wielkości użytków rolnych obrabianych przez rolników. Po wielu reformach, płatności bezpośrednie zostały istotnym instrumentem WPR. Przyczyniają się one m.in. do: zachowania użytków rolnych w dobrej kulturze, podwyższenia stopnia ochrony środowiska, wyrównywania kosztów związanych $\mathrm{z}$ wymogami unijnymi, pomagania $\mathrm{w}$ zachowaniu zasad równej konkurencji na rynku, a także podnoszenia poziomu życia w małych gospodarstwach.

Oprócz bezpośrednich płatności, Polacy w wyniku wstąpienia w szeregi Unii Europejskiej, mogą korzystać z szeregu innych dofinansowań. Do tej pory można było pozyskiwać środki z programów 2004-2006 i 2007-2013, cały czas natomiast można korzystać z programu 2014-2020. Są one uważane za jeden z najważniejszych czynników warunkujących rozwój gospodarstw [Żmija 2016: 50]. Instrumenty Wspólnej Polityki Rolnej tworzą grupę czynników zewnętrznych, są one uzupełnianie czynnikami wewnętrznymi, jak np.: zasoby czynników produkcji [Poczta i in. 2012: 207]. Program 2004-2006 był pierwszym, z jakiego skorzystali polscy rolnicy. Opierał się on na dwóch filarach. Pierwszym były dopłaty bezpośrednie oraz instrumenty wsparcia rynkowego, a drugim Plan Rozwoju Obszarów Wiejskich, czyli PROW. PROW 2007-2013 wniósł jednak pewne zmiany, główną z nich było wprowadzenie czterech osi. Pierwsza $\mathrm{z}$ nich miała na celu poprawę konkurencyjności sektora rolnego i leśnego. Zadaniem drugiej była poprawa stanu środowiska naturalnego, ale także obszarów wiejskich. Oś trzecia odpowiadała za różnicowanie gospodarki wiejskiej oraz poprawę jakości życia rolników. Ostatnia z nich (LEADER) miała na celu aktywizację mieszkańców terenów wiejskich. Obecny PROW jest przede wszystkim ukierunkowany na ochronę środowiska, rozwój rolnictwa ekologicznego, a także wspieranie inicjatywy LEADER. Jego głównym zadaniem jest poprawa konkurencyjności sektora rolnego. Środki, jakie mają być przeznaczone na ten program, to $13,5 \mathrm{mld}$ euro, 8,6 mld z budżetu Unii, a około 4,0 mld z budżetu Skarbu Państwa. 


\section{STUDIUM PRZYPADKU}

Przedsiębiorstwo rolne, które było przedmiotem badań, znajduje się w centralnej Polsce. Ogólna powierzchnia gospodarstwa wynosi 57 hektarów. Przedsiębiorstwo specjalizuje się w produkcji zwierzęcej, odchowywane są w nim opasy sztuk, a także krowy, mleko dostarczane jest do OSM Łowicz. Całkowite pogłowie gospodarstwa mieści się $\mathrm{w}$ granicach 70 sztuk. Wartość gospodarstwa szacowana jest na $3405500 \mathrm{zk}$, a dochody oscylują w granicy 360000 zł. rocznie.

W latach 2010-2017 przedsiębiorstwo trzykrotnie składało wnioski w celu pozyskania dofinansowania ze środków unijnych. Każdy z nich został finalnie rozpatrzony pozytywnie. Wnioski były sporządzane we współpracy z pracownikami Łódzkiego Ośrodka Doradztwa Rolniczego w Bratoszewicach. Dokumenty do dofinansowania złożone zostały w Agencji Restrukturyzacji i Modernizacji Rolnictwa w Łodzi. Wnioski dotyczyły projektów ujętych w tab. 3.

Tabela 3. Projekty przedsiębiorstwa

\begin{tabular}{|l|c|c|c|}
\hline Nazwa projektu & $\begin{array}{c}\text { Przyznana kwota } \\
\text { dofinansowania (zl) }\end{array}$ & $\begin{array}{c}\text { Data przyznania } \\
\text { pomocy }\end{array}$ & Program \\
\hline $\begin{array}{l}\text { Ułatwianie startu } \\
\text { młodym rolnikom }\end{array}$ & 75000 & 14.12 .2010 & PROW 2007-2013 \\
\hline $\begin{array}{l}\text { Modernizacja } \\
\text { gospodarstw rolnych }\end{array}$ & 104750 & 20.07 .2012 & PROW 2007-2013 \\
\hline $\begin{array}{l}\text { Modernizacja } \\
\text { gospodarstw rolnych }\end{array}$ & 79100 & 01.12 .2016 & PROW 2014-2020 \\
\hline
\end{tabular}

Źródło: opracowanie własne na podstawie materiałów źródłowych przedsiębiorstwa.

W 2010 roku przedsiębiorstwo otrzymał pierwsze dofinansowanie w ramach działania „Ułatwianie startu młodym rolnikom” objętego Programem Rozwoju Obszarów Wiejskich na lata 2007-2013. Środki na dofinansowanie pochodziły z Europejskiego Funduszu Rolnego na Rzecz Rozwoju Obszarów Wiejskich. Decyzja o przyznaniu płatności została wydana 14 grudnia 2010 r. Pomoc finansowa w wysokości 75 tys. zł została przyznana w jednej transzy. Za kwotę 40 tys. zł zakupiono i zamontowano dojarkę przewodową. W efekcie inwestycji skrócony został czas dojenia oraz wzrosła liczba pogłowia dojonego jednocześnie. Kolejną zaletą takiego rozwiązania jest racjonalne wykorzystanie pracy właściciela. Za pozostałe 35 tys. zł zostały zakupione wysokocielne jałówki. Zostały one sprowadzone $\mathrm{z}$ Czech, w celu zwiększenia średniej wydajności stada. Zwierzęta pochodziły z hodowli, która może pochwalić się bardzo dobrym materiałem genetycznym. Poprzez inseminację zakupionych jałówek, 
wysokiej klasy nasieniem, właściciel gospodarstwa zbudował stado o dobrej genetyce oraz wysokiej wydajności.

Wymogami, jakie musiał spełnić właściciel w terminie nie przekraczającym 3 lat od momentu otrzymania decyzji o przyznaniu pomocy było:

- „nabycie gospodarstwa wskazanego w biznesplanie,

- podjęcie samodzielnego prowadzenia gospodarstwa,

- ubezpieczenia na podstawie przepisów o ubezpieczeniu społecznym rolników z mocy ustawy w pełnym zakresie jako rolnik,

- uzyskanie wpisu do ewidencji producentów, stanowiącej część krajowego systemu ewidencji producentów, ewidencji gospodarstw rolnych oraz ewidencji wniosków przyznanie płatności, jeżeli jako małżonek nie został dotychczas wpisany do tej ewidencji” [Rozporządzenie Ministra Rolnictwa i Rozwoju Wsi z dnia 17 października 2007 r..., Dz.U. 2007, nr 200, poz. 1443. z późn.zm. §15 ust. 3].

Dokumenty potwierdzające spełnienie wymogów zostały przez Beneficjenta doręczone do oddziału regionalnego ARiMR.

W 2012 r. przedsiębiorstwo otrzymało drugą dotację dla projektu „Modernizacja gospodarstw rolnych" w ramach Programu Rozwoju Obszarów Wiejskich na lata 2007-2013, finansowaną ze środków Europejskiego Funduszu Rolnego na rzecz Rozwoju Obszarów Wiejskich. Umowa dotycząca przyznania pomocy została zawarta 20 lipca 2012 r. w Łodzi.

Stronami w umowie była ARiMR z siedzibą w Warszawie i przedsiębiorstwo rolne. Pomoc została wypłacona w jednej transzy w wysokości $104750 \mathrm{zł}$. $\mathrm{Z}$ przyznanej dotacji zakupiono ciągnik Case Maxxmum $125 \mathrm{c}$ za kwotę 270 tys. zł. Wkład własny wyniósł 165250 zł, z czego 100 tys. zł zostało pokryte z zaciągniętego w tym celu kredytu, natomiast 65250 zł zapłacono ze środków własnych gospodarstwa. Inwestycja ta pozwoliła na skrócenie czasu wykonywania prac polowych. Ciągnik ten stał się główną siłą roboczą gospodarstwa, zastępując o wiele mniejszej mocy Zetor $7045 \mathrm{w}$ najcięższych pracach polowych. Ma on moc znamionową wynoszącą $125 \mathrm{KM}$, a więc o $55 \mathrm{KM}$ więcej niż wspomniany wcześniej Zetor. Pozwala to na skorzystanie z agregatu uprawowo siewnego, dzięki czemu pole jednocześnie jest przygotowywane pod zasiew i obsiewane. Kolejną maszyną pozwalającą na oszczędności był zakup pługa obrotowego. Zainwestowanie w zakup nowych i większych maszyn, pozwoliło na jednoczesne wykonywanie kilku zabiegów i obrabianie większej powierzchni pola. Umożliwia to zaoszczędzenie czasu pracy, a także kosztów związanych z zużyciem paliwa. Kolejnym atutem tej inwestycji są obniżone koszty utrzymania maszyny. Ciągnik został kupiony u dilera i jako nowa maszyna objęty gwarancją, wobec tego koszty serwisu i napraw ograniczono do minimum. 
Tabela 4. Trzecia dotacja przedsiębiorstwa

\begin{tabular}{|l|c|c|}
\hline Nazwa maszyny & Cena (zł) & Data zakupu \\
\hline Prasa Case IH RB 344 & 98000 & 10.02 .2017 \\
\hline Gruber & 18000 & 10.02 .2017 \\
\hline Paszowóz Alima evolution 8 & 80000 & 23.08 .2017 \\
\hline Razem & $\mathbf{1 9 6 0 0 0}$ & \\
\cline { 1 - 2 } Dotacja & 79100 & \\
\cline { 1 - 2 } Wkład własny & 116900 & \\
\cline { 1 - 2 } & &
\end{tabular}

Źródło: opracowanie własne na podstawie materiałów źródłowych przedsiębiorstwa.

W 2016 roku przedsiębiorstwo otrzymało trzecią dotację z projektu „Modernizacja gospodarstw rolnych" w ramach Programu Rozwoju Obszarów Wiejskich na lata 2014-2020, finansowana ze środków Europejskiego Funduszu Rolnego na rzecz Rozwoju Obszarów Wiejskich. Umowa dotycząca przyznania pomocy została zawarta 01 grudnia $2016 \mathrm{r}$. w Łodzi. Stronami w umowie była ARiMR z siedzibą w Warszawie oraz przedsiębiorstwo rolne. Pomoc w wysokości 79100 zł została przyznana w jednej transzy. Pierwszą maszyną jaka została zakupiona z przyznanej dotacji była prasa zwijająca Case IH Rb 344, której cena wyniosła 98 tys. Inwestycja ta pozwoliła na skrócenie czasu pracy. Prasa wyposażona jest w noże tnące oraz rotor, co powoduje, że pasza przygotowywana ze sporządzonych przez nią bel, będzie miała większą wartość odżywczą dla bydła, a także skróceniu ulegnie czas sporządzania paszy TMR (Total Mixed Ration). Dodatkowo prasa wyposażona jest $\mathrm{w}$ podbieracz o szerokości roboczej $2 \mathrm{~m}$, co ogranicza straty w zbiorach.

Drugą z zrealizowanych inwestycji jest zakup agregatu ścierniskowego. Całkowity koszt nabycia maszyny wyniósł 18 tys. zł. Głównym zadaniem agregatu ścierniskowego jest wykonywanie uprawy pożniwnej, która powoduje spulchnienie gleby, wymieszanie resztek pożniwnych z glebą oraz wyrównanie powierzchni pola. Dotacja pokryła także część kosztów związanych z zakupem paszowozu. Przedsiębiorstwo zapłaciło za maszynę 80 tys. zł. Inwestycja ta pozwoliła na zastosowanie w żywieniu bydła systemu paszy TMR. Technologia pozwala na polepszenie się zdrowotności krów, zwiększenie pobierania suchej masy, co ma wpływ na poprawę wydajność mlecznej krów, a także przyrost masy ciała u bydła opasowego. Następną korzyścią jest racjonalne wykorzystanie zasobów pracy ludzkiej oraz zmniejszenie czasu pracy związanego z karmieniem pogłowia. Całkowity koszt maszyn zakupionych przez przedsiębiorstwo wyniósł 196 tys. zł, z czego 116900 zł był to wkład własny.

Efektem uzyskanych dofinansowań był znaczny wzrost wielkości ekonomicznej przedsiębiorstwa rolnego. Pozyskane pieniądze pozwoliły na unowo- 
cześnienie oraz uzupełnienie parku maszynowego. Zwiększeniu uległo także pogłowie bydła, co wiąże się ze wzrostem dochodów z podstawowej działalności. Pomimo zwiększonego pogłowia, poprzez zastosowanie nowych rozwiązań technologicznych, czas poświęcany na pracę przy zwierzętach uległ skróceniu.

Tabela 5. Ocena zakupu jałówek

\begin{tabular}{|l|c|c|c|c|}
\hline \multirow{2}{*}{ Wyszczególnienie } & \multicolumn{2}{|c|}{$\begin{array}{c}\text { Średnia wydajność 1 jałówki stada } \\
\text { podstawowego gospodarstwa } \\
\text { „Agrolux”w 2011 r. (bez jałówek } \\
\text { zakupionych z dotacji) }\end{array}$} & \multicolumn{2}{|c|}{$\begin{array}{c}\text { Średnia wydajność 1 jałówki } \\
\text { zakupionej z dotacji w } 2011 \mathrm{r} .\end{array}$} \\
\cline { 2 - 5 } & $\begin{array}{c}\text { Liczba 1. mleka } \\
\text { Dzień }\end{array}$ & Dochód & Liczba 1. mleka & Dochód \\
\hline 30 dni (miesiąc) & 600 & 26 & 30 & 39 \\
\hline $\begin{array}{l}1 \text { laktacja } \\
\text { (10 miesięcy) }\end{array}$ & 6000 & 7800 & 900 & 1170 \\
\hline
\end{tabular}

*dochód obliczony zostało na podstawie średniej ceny mleka w mleczarni OSM Łowicz w 2011 roku

** laktacja to okres wydzielania mleka u krowy

*** gospodarz zakupił 8 jałówek z dotacji

Źródło: opracowanie własne na podstawie materiałów źródłowych przedsiębiorstwa.

Jak wynika $\mathrm{z}$ danych zaprezentowanych $\mathrm{w}$ tab. 5, dostarczonych przez przedsiębiorstwo, jedna jałówka stada podstawowego, nie wliczając jałówek zakupionych z dotacji w 2011 roku, oddawała dziennie 20 l. mleka. Według danych z tabeli średnia dzienna wydajność jednej jałówki zakupionej z dotacji w 2011 r. wyniosła 30 l. W okresie jednej laktacji jałówki zakupione z dotacji oddają średnio o 3 tys. 1. więcej białego surowca. Uwzględniając przeciętną cenę z 2011 r. w mleczarni OSM Łowicz wynoszącą 1,30 zł, jedna jałówka zakupiona $\mathrm{z}$ dotacji dostarcza $\mathrm{w}$ okresie jednej laktacji 9000 l. mleka, co daje przychód w wysokości 11700 zł. Przedsiębiorstwo dokonało zakupu 8 jałówek, co zwiększyło jego roczny dochód z produkcji mleka o 93600 tys. zł. Każda z jałówek urodziła w 2011 r. jedno cielę. Wartość jednego cielaka w 2011 r. wynosiła przeciętnie 650 zł, co dodatkowo zwiększyło wartość majątku gospodarstwa o 5200 zł. Całość inwestycji przynosi gospodarzowi corocznie średnio $98800 \mathrm{zl}$.

Zamontowana dojarka przewodowa firmy De Laval zastąpiła w przedsiębiorstwie dojarkę konwiową Afla Laval Archimedes. Dojarka poprzez zastosowanie rurociągu, którym transportowane jest mleko, pozwala na zaoszczędzenie czasu, a także zasobów pracy ludzkiej. Użytkowanie dojarki przewodowej wpływa na jakość uzyskiwanego mleka. W wyniku zamontowania wydajniejszej pompy rolnik może doić od 4 do 8 krów jednocześnie. Czas dojenia stada pod- 
stawowego przedsiębiorstwa został skrócony z 3 godzin do 1 godziny. Inwestycja ta podnosi znacznie komfort pracy. Wadą dojarki przewodowej jest natomiast koszt utrzymania, który jest o 1300 zł miesięcznie wyższy niż dojarki konwiowej.

Tabela 6. Ocena zakupu i montażu dojarki przewodowej

\begin{tabular}{|l|c|c|}
\hline \multirow{2}{*}{ Wyszczególnienie } & \multicolumn{2}{|c|}{ Nazwa dojarki } \\
\cline { 2 - 3 } & Alfa Laval Archimedes & De Laval \\
\hline Typ dojarki & konwiowa & przewodowa (rurociągowa) \\
\hline Ilość aparatów udojowych & 2 & 4 \\
\hline Czas dojenia 30 krów (h) & 3 & 2000 \\
\hline $\begin{array}{l}\text { Miesięczne koszty utrzymania } \\
\text { (z) }\end{array}$ & 700 & 1 \\
\hline
\end{tabular}

Źródło: opracowanie własne na podstawie materiałów źródłowych przedsiębiorstwa.

Tabela 7. Ocena zakupu ciągnika Case Maxxum $125 \mathrm{c}$

\begin{tabular}{|l|c|c|c|c|}
\hline \multirow{2}{*}{ Wyszczególnienie } & \multicolumn{4}{|c|}{ Marka ciągnika } \\
\cline { 2 - 5 } & \multicolumn{2}{|c|}{ Zetor 7045 } & \multicolumn{2}{c|}{ Case Maxxum 125 c } \\
\cline { 2 - 5 } & $\begin{array}{c}\text { Szerokość } \\
\text { robocza (m) }\end{array}$ & $\begin{array}{c}\text { Wydajność na } \\
1 \text { godz. pracy (ha) }\end{array}$ & $\begin{array}{c}\text { Szerokość } \\
\text { robocza (m) }\end{array}$ & $\begin{array}{c}\text { Wydajność na } \\
1 \text { godz. pracy ha }\end{array}$ \\
\hline Orka & 0,9 & 0,5 & 1,8 & 1,5 \\
\hline $\begin{array}{l}\text { Przygotowanie do zasie- } \\
\text { wu }\end{array}$ & 2,8 & 2 & 3 & 2,5 \\
\hline Zasiew & 3 & 2,5 & 3 & 2,5 \\
\hline Uprawa pożniwna & 1,8 & 1,2 & \multicolumn{2}{|c|}{125} \\
\hline Moc znamionowa $(\mathrm{km})$ & \multicolumn{2}{|c|}{70} & & 3 \\
\hline
\end{tabular}

Źródło: opracowanie własne na podstawie materiałów źródłowych przedsiębiorstwa.

W tabeli 7 zostały przedstawione podstawowe dane techniczne na temat zabiegów jakie wykonywane są przez ciągnik Case Maxxum 125 c finansowanego dotacją. Jak wynika $\mathrm{z}$ informacji zawartych $\mathrm{w}$ tab. 7, w ciągu jednej godziny zabieg orki wykonywany jest na trzykrotnie większej powierzchni pola. Proces przygotowania do zasiewu oraz siew, poprzez wykorzystanie agregatu uprawowo siewnego, jest wykonywany jednocześnie, co pozwala na zaoszczędzenie czasu, a także ogranicza koszty związane z zużyciem paliwa. Wydajność pracy podczas wykonywania uprawy pożniwnej zwiększyła się o 1,3 ha/h. Poprzez wykorzystanie maszyn o większej szerokości roboczej, czas wykonywania pracy w przedsiębiorstwie został skrócony, co pozwala na świadczenie usług generują- 
ce dodatkowy przychód dla gospodarstwa. Całość inwestycji jest bardzo ważna z punktu widzenia rozwoju przedsiębiorstwa. Większe maszyny pozwalają na obrabianie większej powierzchni uprawowej. Dodatkowo ciągnik Case Maxxum 125 c oferuje możliwość zwiększenia swojej mocy do $160 \mathrm{KM}$, co w przyszłości może pozwolić na zaoszczędzenie jeszcze większej ilości czasu.

Tabela 8. Ocena zakupu prasy Case IH RB 344

\begin{tabular}{|l|c|c|}
\hline \multirow{2}{*}{ Wyszczególnienie } & \multicolumn{2}{|c|}{ Nazwa prasy } \\
\cline { 2 - 3 } & Welger RP 15 & Case IH RB 344 \\
\hline Wysokość beli $(\mathrm{cm})$ & 150 & 120 \\
\hline Szerokość podbieracza (cm) & 140 & Owijanie sznurkiem bądź siatką \\
\hline System owijania & Owijanie sznurkiem & Centralne smarowanie, rotor, noże tnące \\
\hline Wyposażenie dodatkowe & brak & 10 \\
\hline \multicolumn{2}{|c|}{ Cennik usług (zł) } \\
\hline Prasowanie bez noży tnących & \multicolumn{2}{|c|}{15} \\
\hline Prasowanie z włączonymi nożami tnącymi
\end{tabular}

Źródło: opracowanie własne na podstawie materiałów źródłowych przedsiębiorstwa.

Prasa Case IH RB 344 zastąpiła w przedsiębiorstwie prasę Welger RP 15. W prasie Case IH RB zastosowano system owijania sznurkiem bądź siatką. Obecnie belki owijane są wyłącznie przy użyciu siatki. Belka jest owijana siatką 2 razy, poprzednio przy użyciu sznurka, w zależności od ustawienia było to od 10 do 16 razy. Jeden obrót komory prasy zajmuje około 5 sekund, przy ustawieniu owijania sznurkiem na 12 razy owinięcie jednej belki zajmuje około 1 minuty. Zastosowanie siatki skraca ten czas do 10 sekund. W przedsiębiorstwie rocznie prasuje się przeciętnie 1500 bel, wykorzystując technologię owijania siatką może on oszczędzić corocznie około 20 godzin pracy. Istotną korzyścią inwestycji jest jej wyposażenie dodatkowe. W prasie zostało zastosowane centralnie smarowanie łańcuchów, sprzyja to dłuższej żywotności sprzętu. Ponadto prasa wyposażona jest $\mathrm{w}$ rotor oraz noże tnące, co pozwala na rozdrabnianie zbieranej paszy. Przedsiębiorstwo w momencie zakupu prasy rozpoczęło świadczenie usług prasowania. W 2017 roku wykonało usługę prasowania 230 bel bez użycia noży tnących, co przyniosło 2300 zł przychodu oraz 370 bel z życiem noży tnących co dało $5550 \mathrm{zl}$.

Agregat ścierniskowy zastąpił wykorzystywaną poprzednio przez przedsiębiorstwo bronę talerzową. Brona talerzowa była wypożyczana za kwotę $100 \mathrm{zł}$ dziennie. Rolnik użytkował maszynę 6 dni, w ciągu roku co generowało koszty w wysokości 600 zł. Inwestycja pozwoliła na ograniczenie kosztów związanych $\mathrm{z}$ wypożyczeniem maszyny. Jak wynika $\mathrm{z}$ danych w tabeli 8 skróceniu uległ czas 
wykonywania uprawy pożniwnej, ponieważ wykorzystując zakupiony gruber rolnik jest $\mathrm{w}$ stanie uprawić $\mathrm{w}$ ciągu jednej godziny o 1,3 ha powierzchni uprawnej więcej.

Tabela 9.Ocena zakupu wozu paszowego

\begin{tabular}{|l|c|c|}
\hline Wyszczególnienie & $\begin{array}{c}\text { Zadawanie paszy bez wozu } \\
\text { paszowego }\end{array}$ & $\begin{array}{c}\text { Zadawanie paszy przy użyciu } \\
\text { wozu paszowego }\end{array}$ \\
\hline Liczba pracowników & 3 & 2 \\
\hline Czas pracy (h) & 2 & 1 \\
\hline
\end{tabular}

Źródło: opracowanie własne na podstawie materiałów źródłowych przedsiębiorstwa.

Zakupiony przy pomocy środków Unijnych wóz paszowy pozwala na zmniejszenie liczby pracowników potrzebnych do zadawania paszy z 3 do 2 . Wynika to $\mathrm{z}$ faktu, iż cała pasza jaką otrzymują zwierzęta, mieszana jest w wozie paszowym i nie wymaga osobnego zadawania. Kolejną korzyścią wynikająca z inwestycji jest skrócenie o 1 godzinę czasu pracy. Dodatkowo paszowóz całkowicie mechanizuje rozdawanie paszy, przez co zwiększa się komfort pracy.

\section{PODSUMOWANIE}

Współczesne rolnictwo, to rolnictwo opierające się na innowacyjnych rozwiązaniach technologicznych i organizacyjnych. Jednym ze źródeł finansowania działalności rolniczej są fundusze strukturalne Unii Europejskiej, w tym te skierowane bezpośrednio do sektora rolniczego. Młodzi rolnicy rozpoczynający działalność w zdecydowanej większości przejmują gospodarstwa, w których warunki pracy nie się dostosowane do obecnych standardów. Wsparcie unijne, przejawiające się w programach typu: „Ułatwianie startu młodym rolnikom”, zapewnia lepszy start przyszłym i obecnym rolnikom, a „Modernizacja gospodarstw rolnych" wspiera ich dalszy rozwój. Corocznie otrzymywane dopłaty bezpośrednie pozwalają rolnikom na zakup nawozów lub maszyn. Są one fundamentalnym środkiem, który pozwala na zwiększenie produktywności uprawianej ziemi. Analizując coroczny budżet Unii Europejskiej możemy zauważyć, że każdego roku połowa całkowitej sumy budżetowej przeznaczana jest na rozwój rolnictwa, co świadczy o wyjątkowej istotności tego tematu.

Celem pracy była ocena wykorzystania środków pomocowych Unii Europejskiej w finansowaniu gospodarstw rolnych w Polsce.

Realizacja celu wymagała przeprowadzania analizy funkcjonowania przykładowego gospodarstwa rolnego, będącego beneficjentem środków Unii Euro- 
pejskiej w latach 2004-2017. Badania przeprowadzono wykorzystując materiały źródłowe przedsiębiorstwa rolnego „Agrolux”. Całkowita powierzchnia gospodarstwa wynosi 58 ha, przez co zalicza się ono do gospodarstw o średniej wielkości. Gospodarstwa średnie są obecnie największymi beneficjentami środków Unii Europejskiej.

Hipoteza mówiąca, że środki pomocowe Unii Europejskiej determinują rozwój ekonomiczny polskich gospodarstw rolnych została rozpatrzona pozytywnie.

W przedsiębiorstwie opisanym $\mathrm{w}$ pracy, fundusze unijne zapoczątkowały szereg fundamentalnych zmian. Pierwszą z nich było dwukrotne powiększenie się gospodarstwa. Środki, jakie otrzymał beneficjent dotacji pozwoliły mu zmodernizować gospodarstwo, a co za tym idzie oszczędzić czas pracy i koszty związane z ich utrzymaniem. Poprawił się komfort pracy, co jest dodatkowym motywatorem do dalszego rozwoju swojej działalności.

\section{BIBLIOGRAFIA}

Informacja nt. możliwych przesunięć środków pomiędzy płatnościami związanymi z produkcją, www.minrol.gov.pl [dostęp 24.11.2017].

Józefowicz K.M., 2015, Polski sektor rolno-spożywczy w warunkach Wspólnej Polityki Rolnej, Uniwersytet Warmińsko-Mazurski w Olsztynie Wydział Nauk Ekonomicznych, Olsztyn.

Kaleta A., 2008, Dywersyfikacja źródeł dochodów ludności wiejskiej, Wydawnictwo Naukowe Uniwersytetu Mikołaja Kopernika, Torun.

Koniunktura w gospodarstwach rolnych w drugim półroczu 2015 roku (wersja rozszerzona), Tabela 5, www.stat.gov.pl [dostęp 25.11.2017].

Otta W., 1998, Działalność kredytowa banku, Wydawnictwo Wyższej Szkoły Bankowej, Poznań.

Rocznik statystyczny pracy, www.stat.gov.pl/obszary-tematyczne/roczniki-statystyczne/rocznikistatystyczne/rocznik-statystyczny-pracy-2017,7,5.html [dostęp 6.02.2019].

Poczta W., Siemiński P., Sierszchulski J., 2012, Przestrzenne zróżnicowanie aktywności rolników $w$ pozyskiwaniu środków unijnych na rozwój gospodarstw rolnych $w$ Wielkopolsce na przykładzie działania ,,Modernizacja gospodarstw rolnych”, ,Journal of Agribusiness and Rural Development", vol. 3(25).

Kłodziński M, Dzuna W. (red.), 2005, Rolnictwo a rozwój obszarów wiejskich, Instytut Rozwoju Wsi i Rolnictwa, Warszawa.

Rozporządzenie Ministra Rolnictwa i Rozwoju Wsi z dnia 17 października 2007 r. w sprawie szczegółowych warunków i trybu przyznawania pomocy finansowej w ramach działania „Ułatwianie startu młodym rolnikom” objętego Programem Rozwoju Obszarów Wiejskich na lata 2007-2013, Dz.U. 2007, nr 200, poz. 1443 z późn.zm. §15, ust. 3.

Runge A., 2008, Stownik pojęć z geografii społeczno-ekonomicznej, Videograf Edukacja, Katowice.

Smid W., 2007, Leksykon przedsiębiorcy, Wydawnictwo POLTEXT, Warszawa.

Szukalski S. M., 2004, Zmiany sektorowej struktury gospodarki polskiej w latach1992-2002 na tle gospodarek Wspólnoty Europejskiej, „Zeszyty Naukowe Wyższej Szkoły EkonomicznoSpołecznej w Ostrołęce”, nr 1, Ostrołęka. 
Zegar J.S., 2008, Dochody w rolnictwie w okresie transformacji i integracji europejskiej, Instytut Ekonomiki Rolnictwa i Gospodarki Żywnościowej, Warszawa.

Żmija D., 2016, Wpływ Wspólnej Polityki Rolnej Unii Europejskiej na funkcjonowanie małych gospodarstw rolnych w Polsce, Difin SA, Warszawa.

\title{
EU ASSISTANCE FUNDS IN THE FINANCIALISING FARMSTEADS
}

\section{- THE CASE STUDY}

\begin{abstract}
The article concerns the importance of European funds in financing the farms in Poland. In recent years, as a result of systemic transformation and Poland's accession to the structures of the European Union, the agricultural sector in Poland has changed a lot. In order to remain competitive, the farms must constantly modernize the machinery park. The EU's assistance funds are currently one of the basic sources of financing a purchase of the new machines. In the European Union the agricultural sector is treated as a priority. Every year, a half of the EU's budget is dedicated to finance the agriculture sector. The purpose of this article is to assess the useage of European Union's aid resources in financing the farms in Poland.
\end{abstract}

Keywords: agriculture, EU funds, agricultural development, agricultural sector. 